УДК 347.7

DOI: $10.26565 / 2075-1834-2020-29-18$

\title{
MITIGATIONS RISK OF TRADEMARK RIGHTS LAW AS CREDIT BANK GUARANTEE
}

Trisadini Prasastinah Usanti, doktoral of law faculty,

University of Airlangga, Indonesia e-mail: trisadiniprasastina@ gmail.com orcid: https://orcid.org/0000-0003-1257-8785

ANNOTATION: credit from the bank balance sheet assets is the largest portion of operational funds but at the same. time it is the largest business risk sources. Credit problem and even bad credit are a problem for banks, because the existence of credit problem is not only decrease the bank incomes but decrease the profit because each credit is categorized as problem credit so the obligation of bank is to make the Provision for Loan Losses (PPKA). The credit analysis is the preventif effort which must be done by the bank carefully and deeply because can play a role as first filter in sharia bank effort to ward off the danger of problem credit. The Efforts to minimize legal risk over brand certificate guarantees in banking practices by conducting a professional analysis of brands. The main thing that is done by the bank is to identify whether the rights to the mark meet the legal and economic requirements as a guarantee and the important is imposition of perfect pawn collateral institutions or fiduciaries then it cause the property rights is born and bank domiciled as a preferred creditor. The analysis on guarantee is the bank effort to ward off legal risk such as weakness of the alliance until not fulfilled the contractual terms or not perfect of collateral binding even the cancellation of the brand certificate. If this is not mitigated, it will be detrimental to the position of the bank as a creditor because the bank is only located as a concurrent creditor. Binding weakness such as the contract's legal requirements are not fulfilled as stipulated in Article $1320 \mathrm{BW}$, which is if not fulfilling the subjective requirement, such as agreement element and proficiency then the agreement can be cancelled (vernietig baar) while if the objective requirement are not fulfilled, it is related with the element of object and cause is allowed then the agreement is cancelled (nietig). The trademark right is already accepting to conventional banks or sharia banks as guarantee object.

KEY WORDS: Mitigations, Legal Risk, Trademark Guarantee, Guarantee, Bank, Credit Bank.

\section{РИЗИК ПОМ'ЯКШЕННЯ ЗАКОНУ ПРО ПРАВА ТОВАРНИХ ЗНАКІВ ЯК ГАРАНТІЯ КРЕДИТНОГО БАНКУ}

\author{
Trisadini Prasastinah Usanti, \\ докторант юридичного факультету, \\ Університет Аірлангга, Індонезія \\ e-mail: trisadiniprasastina@gmail.com \\ orcid: https://orcid.org/0000-0003-1257-8785
}

АНОТАЦІЯ: кредит $з$ активів балансу банку є найбільшою частиною операційних фондів, але в той же час $є$ найбільшим джерелом ділових ризиків. Проблема 3 кредитуванням та навіть поганий кредит є проблемою для банків, оскільки наявність кредитної проблеми - це не лише зменшення доходів банку, а зменшення прибутку, оскільки кожен кредит класифікується як проблемний кредит, тому зобов'язання банку полягає у формуванні резерву для втрат позики (ППКА). Кредитний аналіз - це превентивні зусилля, які повинен докладати банк ретельно і глибоко, тому що вони можуть зіграти роль першого фільтру в зусиллях шаріату, щоб запобігти небезпеці проблемного кредитування. Зусилля щодо мінімізації юридичного ризику щодо гарантій сертифікату бренда у банківській практиці шляхом проведення професійного аналізу брендів. Головне, що робиться банком, - це визначити, чи відповідають права на марку юридичним та економічним вимогам як гарантії, а важливим $\epsilon$ накладення досконалих закладів застави або довірених осіб, тоді це спричиняє народження прав власності та банк перебуває у нас. як кращий кредитор. Аналіз гарантії - це зусилля банку щодо запобігання юридичному ризику, такому як слабкість альянсу до тих пір, поки не будуть виконані договірні умови або не $є$ ідеальним застава, навіть скасування сертифікату бренду. Якщо це не буде пом'якшене, це погіршить позицію банку як кредитора, оскільки банк розташований лише як супутній кредитор. Обов'язкова слабкість, така як юридичні вимоги договору, не виконується, як передбачено статтею 1320 BW, яка є, якщо не відповідає суб'єктивним вимогам, таким як елемент угоди та досвід, тоді договір може бути скасований (vernietig baar), хоча якщо об'єктивної вимоги не буде Виконано, це пов'язано з елементом об'єкта і причиною дозволено, тоді угода скасовується (nietig). Право на торговельну марку вже приймається до звичайних банків або шаріатних банків як об'єкт гарантії.

КЛЮЧОВІ СЛОВА: пом'якшення наслідків, юридичний ризик, гарантія товарних знаків, гарантія, банк, кредит-банк. 


\title{
РИСК СМЯГЧЕНИЯ ЗАКОНА О ПРАВАХ ТОВАРНЫХ ЗНАКОВ КАК ГАРАНТИЯ КРЕДИТНОГО БАНКА
}

\author{
Trisadini Prasastinah Usanti, \\ докторант юридического факультета, \\ Университет Аирлангга, Индонезия \\ e-mail: trisadiniprasastina@gmail.com \\ orcid: https://orcid.org/0000-0003-1257-8785
}

\begin{abstract}
АННОТАЦИЯ: кредит из активов баланса банка является самой большой частью операционных фондов, но в то же время является крупнейшим источником деловых рисков. Проблема с кредитованием и даже плохой кредит является проблемой для банков, поскольку наличие кредитной проблемы - это не только уменьшение доходов банка, a уменьшение прибыли, поскольку каждый кредит классифицируется как проблемный кредит, поэтому обязательства банка заключается в формировании резерва для потерь займа (ППКА). Кредитный анализ - это превентивные усилия, которые должен прилагать банк тщательно и глубоко, потому что они могут сыграть роль первого фильтра в усилиях шариата, чтобы предотвратить опасность проблемного кредитования. Усилия по минимизации юридического риска гарантий сертификата бренда в банковской практике путем проведения профессионального анализа брендов. Главное, что делается банком, - это определить, соответствуют ли права на марку юридическим и экономическим требованиям как гарантии, а важно наложения совершенных заведений залога или доверенных лиц, тогда это влечет рождение прав собственности и банк находится в нас. как лучший кредитор. Анализ гарантии - это усилия банка по предотвращению юридическом риска, таком как слабость альянса до тех пор, пока не будут выполнены договорные условия или не является идеальным залог, даже отмена сертификата бренда. Если это не будет смягчено, это ухудшит позицию банка как кредитора, так как банк расположен всего как сопутствующий кредитор. Обязательное слабость, такая как юридические требования договора, не выполняется, как предусмотрено статьей $1320 \mathrm{BW}$, которая является, если не соответствует субъективным требованиям, таким как элемент соглашения и опыт, тогда договор может быть отменен (vernietig baar), хотя если объективной требования не будут выполнены, это связано с элементом объекта и причиной разрешено, тогда сделка отменяется (nietig). Право на торговую марку уже принимается к обычным банков или шариатных банков как объект гарантии.
\end{abstract}

КЛЮЧЕВЫЕ СЛОВА: смягчение последствий, юридический риск, гарантия товарных знаков, гарантия, банк, кредит-банк.

\section{Introduction}

Credit from the bank balance sheet assets is the largest portion of operational funds but at the same time it is the largest business risk sources. Credit problem and even bad credit are a problem for banks, because the existence of credit problem is not only decrease the bank incomes but decrease the profit because each credit is categorized as problem credit so the obligation of bank is to make the Provision for Loan Losses (PPKA) (Presiden Republik Indonesia, 2019) ${ }^{1}$, this condition in the end can destabilize the bank and eventually detrimental to depositors. Therefore, in (Bank Indonesia, 1992) Article 2 Constitutions Number 7/1992 juncto Constitutions Number 10/1998 regarding to Banks (Banks Constitutions) regulated that Indonesian Banking in doing business based on economic democracy with using the precautionary principle. The application of the precautionary principle aims to the bank always in stable condition, always in the conditions of liquid, solvent and profitable. The application of the precautionary principle is expected so that the level of public trust through the Banks always high until the citizen is ready and no hesitation in depositing funds in the bank (Sjadeini, 1994).

One of the efforts made by banks in minimizing credit risk is by conducting credit analysis. The credit analysis is the preventif effort which must be done by the bank carefully and deeply because can play a role as first filter in sharia bank effort to ward off the danger of problem credit. The credit analysis activity aims to assess the will and ability from prospective recipients of credit facilities in fulfilling the achievements in accordance with the clause in credit agreement. Based on the results of the assessment then the bank can estimates the level of risk bank if agreed those credit.

One of the assessment in credit analysis conducted by bank is by assessing objects to be submitted by debtor customer as guarantee object. The existence of Guarantee (collateral) for credit considered important even though it cannot be said to be absolute. Realizing in Constitution of Banks as confired in Article 8 that the first thing to note is bank confidence in the ability and ability of debtor customers to pay the credit until the guarantee is not become the main requirement in granting credit eventough the exitence of collateral will be important if there is a problem credit. Then if the bank feels confident about the ability and capbility of the debtor customer, the guarantee is a form of goods, project or the bill rights financed with the concerned credit.

One thing that possible becomes the guarantee object in the form of Intellectual Property Rights (HKI), which is involved the trademark rights, copyright, patent, trade secret, industrial design and integrated circuit layout design, besides the guarantees commonly received by banks, which is land rights, the motor vehicle, machine, gold, receivables or claim rights. One of the HKI that has been accepted as guarantee object to conventional bank as well as to syaria bank is trademark rights although only accepted at Banks of BNI Company (persero) and Bank Muamalat Indonesia, as has been done by Sri Mulyani and in the research that I 
have done (Usanti, 2017). The land service has been carried out through various activities using computers, starts from the information until the last result product in the form of decree or freehold title (Widodo et al., 2019).

The trademark right is accept as object of collateral both on conventional banks as well as to sharia banks if the trademark rights has been registered in General Register at the Directorate General of Intellectual Property (DJKI) with proven brand certificate. But, the existence of a trademark certificate does not guarantee the bank will be safe because it is possible for the mark to be canceled. When that happens, the bank is clearly very disadvantaged because with the cancellation of the brand results in the guarantee agreement being deleted and impact on the position of the bank as a creditor. Based on the descriptions above then the problem will be analyze is mitigation risk conducted by the bank on the object of collateral rights to the brand.

\section{Methodology}

This study is using normative method with using statutory and conceptual approach. This study aims to analyze the mitigation risk on object guarantee in the form of trademark rights that conducted by bank. The legal material used is primary legal material, which is Burgerlijk Wetboek (BW), the Constitutions Number 20/2016 (Presiden Republik Indonesia, 2016) about Brands and Geographic indication, the Constitution of Banks, (Presiden Republik Indonesia, 1999) The Constitution Number 42/1999 about the Fiduciary Guarantee and Implementing the Regulation. The secondary legal material is in the form of books, journal, research report, and article.

\section{Risk on the trademark rights as guarantee object}

As stated before that the effort of activity that conducted by banks are full of risks, banks are required to manage those risks. According to Bramanto Djohanoputro that risk is often said to be uncertainty, uncertainty is often interpreted by a situation with several possible event and each event will cause a different results. But, the level of probability and probability of the event itself is not known in quantitatively. While the basic understanding of risk is related to the uncertainty measured quantitatively (Djohanoputro, 2006). In the realm of Civil Law there are teachings about risk (risico leer) which teaches that risk is an unexpected effect. In other words, in the law context then the risk contains nuances of legal uncertainty (Januarita, 2020) ${ }^{2}$.

The meaning of risk based on the Article 1 point 2 Financial Services Authority Regulations Number (Presiden Republik Indonesia, 2019)18/POJK.03/2016 about Application of Risk Management for Commercial Banks (POJK 18/2016) is loss potential cause occurring the certain event. While in Dictionary of Banks, the meaning of risk is the level of possible losses that must be borne in the provision of credit, investment or another transaction it can be form of wealth, losing profit or another economic ability because a change in interest rates, government policy and business failure (risk) ${ }^{3}$. Therefore, bank must apply risk management in effectively. Efforts to apply management Risk is not only intended for the benefit of bank but it is also for customer interest and in the order to risk control is information transparency related with the product or Bank activities. One risk that must managed by banks is related to object guarantee of trademark rights is legal risk. The meaning of legal risk based on POJK 18/2016 is legal risk appear which because lack of supporting constitutions or bound weakness such as the contract's legal requirements are not fulfilled or not perfect the binding of collateral. Based on Black's Law Dictionary means with the legal risk is: Potential affect in debt service or loan recovery as a probability caused by a defect in loan documentation (The Law Dictionary, 2020) ${ }^{4}$.

Binding weakness such as the contract's legal requirements are not fulfilled as stipulated in Article $1320 \mathrm{BW}$, which is if not fulfilling the subjective requirement, such as agreement element and proficiency then the agreement can be cancelled (vernietig baar) while if the objective requirement are not fulfilled, it is related with the element of object and cause is allowed then the agreement is cancelled (nietig). If the credit agreement as main agreement cancel then the guarantee of agreement as accessoire/additional agreement is cancelled. Realizing the existence of the agreement guarantee depend on the basic agreement, which is credit agreement. If the guarantees of agreement cancel then resulting in the position of the bank only as a concurrent creditor, which is creditor is only guaranteed by the general guarantee as stipulated in Article $1131 \mathrm{BW}$.

Legal risk can cause if binding of agreement is not perfect. If the brand has not been registered so there is no brand certificate and if the bank accept as guarantee the binding of guarantee is not perfect because the Brand certificate is the proof of ownership on those brands. In brand certificate includes:

a. Name and Full Address of registered trademark owner

b. Name and Full Address of the Power of Attorney, in the case of an Application through a Proxy

c. Receipt date

d. The country name and the receipt date of the application for the first time in the case of an application being filed using Priority Rights

e. Brand Labels that are registered, including information on the kinds of colors if the Brands use color elements, and if the Brands use a foreign language, letters other than Latin letters, and/or numbers that are not commonly used in Indonesian accompanied by translations in Indonesian, Latin letters and numbers that are commonly used in Indonesian and how to pronounce them in Latin spelling

f. Number and registered date

g. Class and types of goods and/or services whose marks are listed; and 
h. The period of validity of a Trademark registration.

The other legal risk is the existence of the cancellation of the brand taken by one of the parties to search and remove the registration existence from a brand of General Brand List or existence invalidates rights based on brand certificates. In general, the party believes that he has been harmed by the registration so that he may submit a cancellation petition (Cantika, 2018). The claim for cancellation of a registered brand is submitted to the Commercial Court by an interested party based on the based on reasons as regulated in (Presiden Republik Indonesia, 2016) Article 20 and/or Article 21 of the Trademark and Geographical Indications Law. The brand owner is not registered ${ }^{5}$ can file a lawsuit after submitting an application to the minister. The claim of cancellation of a registered brand can only be submitted within a period of 5 (five) years from the date of trademark registration. Cancellations can be filed indefinitely if there is an element of bad faith and/or The Brand concerned is against the ideology of the state, Laws and regulation, Morality, religion, decency, and general order. Commercial Court Decision on the cancellation can be submitted a cassation. The brand cancellations cause the brand crossed out in General Brand List and brand certificate become is no longer valid. If the brand certificate is no longer valid again then the guarantee agreements become removed realizing the guarantee object was considered destroyed. As a result of the law the bank is no longer positioned as a preferred creditor but changed as a concurrent creditor.

\section{Mitigation Risk by Bank}

The Efforts to minimize legal risk that must be carried out by banks on collateral objects in the form of rights to brands is conduct an analysis of collateral objects. The main thing to do is to identify whether the rights to the mark meet the legal and economic requirements as collateral: (Usanti, Trisadini Prasastinah, 2017)

1. Preferred Trademark rights are owned by the potential Debtor customer, if the third party owned then ownership must be ensured.

2. Trademark rights are not in disputes because it is possible that brand certificates can be canceled, making it risky for banks.

3. Trademark rights are accepted as guarantee object if the trademark rights are registered Trademark rights in General Register of Trademark Rights in Directorate General of Intellectual Property Ministry of Law and Human Rights Republic of Indonesia with evidenced the existence of a Brand Certificate.

4. Bank must notice the period of protection of trademark rights, because the legal protection on Trademark Rights is registered for 10 years from the date of receipt. As example: receipt date of the application for registration of Trademark Right is 1 May 2019 then the protection will apply until 1 May 2029. The period of protection of trademark rights can be extended every 10 years continuously as long as the trademark rights concerned are still in used in the goods and services as listed Trademark Certificate and goods or the service is still in production and/or traded. If it is not used and no longer produced and/or traded, the application will be rejected. The holder of Trademark rights can already apply for an extension of Trademark Rights from 6 (six) month before the end of the Trademark rights protection period is registered and applications for extension can still be submitted no later than 6 (six) months after the end of the Trademark Rights protection period. This provisions means the owner of Trademark Rights it is not easy to lose the Trademark Right as a result of the delay in submitting an extension of registration of the Trademark Right.

5. Banks must request the financial statements of the company which owns the rights to the trademark to know whether the rights to the brand have value or not.

6. Banks considering that the Trademark Right is Trademark Right that has a good reputation and has a market share.

7. Economic value in trademark right must be stable and it will be better if it increases.

8. Especially for Sharia Bank, have to make sure that Trademark Rights from halal products not from illegitimate products.

9. The Trademark right is free and is not being guaranteed by another party.

If is already fulfill the Juridical requirement and economic then the important thing must do by bank is burden it with the guarantee agency. The guarantee agency is possibly to burden is fiduciary guarantee agency or mortgage insurance agency (Usanti, Trisadini Prasastinah dan Silvia, 2018). As in Bank of BNI Company (Persero) is using fiduciary guarantee agency while mortgage insure agency used by Bank Muamalat Indonesia. Guarantee burden on trademark right become very important realizing the position of the bank as a creditor is determined by the imposition of a perfect guarantee. The meaning of perfect is the guarantee burden cause the goods right born until the bank position as preference creditor. This thing can be illustrate in the table below: 
Table 1. Burden Rights to Trademark Rights as Guarantee

\begin{tabular}{|l|l|l|l|}
\hline No. & Information & Mortgage & Fiduciary Guarantee \\
\hline 1 & Legal Basis & Article 1150-1160 BW & $\begin{array}{l}\text { Constitutions Number 42/1999 } \\
\text { Regarding the Fiduciary Guarantee } \\
\text { (UUJF) }\end{array}$ \\
\hline 2 & Deed Form & $\begin{array}{l}\text { Based on The Article 1151 } \\
\text { BW pledge agreement in } \\
\text { written form }\end{array}$ & $\begin{array}{l}\text { Based on the Article 5 paragraph } \\
\text { (1) UUJ must be in the form of an } \\
\text { authentic deed drawn up by a } \\
\text { notary }\end{array}$ \\
\hline 3 & $\begin{array}{l}\text { Property rights } \\
\text { born }\end{array}$ & $\begin{array}{l}\text { When the object is handed } \\
\text { over to a creditor or third party } \\
\text { (inbezitstelling), Article 1152 } \\
\text { (1) BW }\end{array}$ & $\begin{array}{l}\text { When registered in electronically } \\
\text { with the Law and Human Rights } \\
\text { Office and recorded in the } \\
\text { fiduciary registry office database, } \\
\text { Article 14 paragraph 3) UUJF } \\
\text { juncto Government Regulation } \\
\text { Number 21/2015 concerning } \\
\text { Procedures for Registration of } \\
\text { Fiduciary Guarantees and Costs for } \\
\text { Making Fiduciary Guarantees Deed }\end{array}$ \\
\hline 4 & $\begin{array}{l}\text { Parties } \\
\text { Registered }\end{array}$ & $\begin{array}{l}\text { In the mortgage there is no } \\
\text { registration }\end{array}$ & $\begin{array}{l}\text { Submitted by Fiduciary Recipients, } \\
\text { their attorneys or representatives }\end{array}$ \\
\hline
\end{tabular}

Resources: own study

Between the perfect burdens then needed to prepared clause in a pawning and fiduciary guarantee agreement to provide legal protection for banks as creditors. For example, the minimum requirements contained in a pawn agreement are as follows: (Usanti, 2017)

In connection with using of Trademark Right by pawnbroker, that while wanprestasie (breach of contract) is not happen and discontinue to pawnbroker have the right to use the entire right in connection with the Trademark Right in connection with the third and gives the right to the third party to use Trademark Right as contained in the Trademark Rights certificates.

Related with benefits and shares. As long as there is no breach of promise the pawnbroker has the right to receive and maintain any and all other profits and shares paid in connection with the Trademark Right. After breach of promises then the entire rights from pawnbroker to grants third-party name usage rights and other divisions cease to exist and after that all such rights to mortgagee. The mortgagee has solitaire right to receive and maintain of the Trademark Right and profit sharing.

In connection with a prohibition that must be obeyed by the pawnbroker. That pawnbroker no transfer or burdening is permitted of Trademark Right in any form. Pawnbroker is prohibiting using Trademark Right with which are contrary to the interests of the pawn recipient.

Clause related the solving lawsuit. In the event of injury to the pledge recipient to the extent permitted by applicable law can take all actions that in his own decision are deemed necessary to protect each of his rights under this agreement, including but not limited to selling, transferring, transferring or otherwise submitting any part of the brand certificate through direct sales, auction sales or through any other method permitted by applicable conditions.

Trademark registration in Indonesia in practice, using constitutive system. In this system, the registrant must register the brand to get protection. This system is also known as First to File system. This system confirm that the first man who register the brand then he has the tight on the brand. Indonesia adhere to brand register constitutive system, the protection of famous brand which not registered in Indonesia will still get the protection, because Indonesia is already ratify Paris Convention and TRIPS Agreement. Application of the principle of first to file is considered to be able to create:

1. Legal certainty to condition who actually owns the most important brand to be protected;

2. The proof of legal certainty, because only based on the fact of register from brand certificate. Register or brand certificate become the only one proof from primary evidence;

3. Achieve alleged law who the brand owner is most entitled to with certainty, not cause the controversial between the first register and first user (Novianti, 2017) ${ }^{6}$.

The owner of brand register have exclusive rights to prevent all the third party is not have the permission to use in trading activities, the same signs, for goods or service which in identical or similar, with the good or service on which the registered of trade brand where the using will cause confusion (Djuwityastuti, dan Ahmad, 2019). It was stated by Nisrina Atikah that: (Atikah, 2019)

In Indonesia, registered trademark owner has exclusive right to use their trademark and give permission to another party to use their trademark. Based on TRIPS Agreement is affirmed that registered trademark owner has 
exclusive right to prevent third party who does not have the owner permission, to use it on trading activity, signs which have similarity, for the same commodity or service or similar with commodity or service on registered trademark, where it must be predicted before that is usage can cause a like hood of confusion. If a trademark is agreed to be registered, then registered trademark owner has exclusive right to use that registered trademark. There are two systems which are believed in trademark registration which are declarative system and constitutive system (attributive).

Beside it there is some advantage from brand protection, which is: (Novianti, 2017) ${ }^{7}$

1. The Brands can product income for company from license, selling, commercialization from the protection of the brand.

2. The brands can increase values or guarantee in the eye of investor and financial institution.

3. In selling or merger asset brand can increase the company value in significant.

4. The brand increases the performance and competitiveness.

5. With brand register is help the protection and enforcement of its rights

The existence of brand as guarantee and the important meaning to minimize the risk on guarantee object in the form of trademark right must concern by credit provider, as stated by (Nguyen, Xuan-Thao and Hile, 2018) ${ }^{8}$ :

Trademarks have an illustrious history of serving as collateral in financing deals for business. A company in need of financing as far back as in the area of chattel mortgage could include trademarks in the mortgage grant for a loan. Then, if the company failed to repay the loan or meet its obligations under the mortgage agreement, the mortgagee would employ an agent to succeed to the mortgagor's business; it was the only way to foreclose on the trademark collateral. Much has changed in the financing landscape where trademarks are part of the collateral. One thing that does not changes, however, the creditors wanting to reduce their risks.

According to Deborah Schvey Ruff, Mayer Brown \& Platt and as quoted by Sri Mulyani that the use of trademarks as a collateral for safe financing has become a dancing choice for borrowers. The trade brand as part of HKI recognized more interesting rather than the kind of the other guarantee because the credit risk is lower and often trademark guarantee agreements will allow borrowers to secure financing without the need to change their capital structure (Mulyani, 2012).

\section{Conclusion}

The trademark right is already accepting to conventional banks or sharia banks as guarantee object. But, bank must anticipate the legal risk which possible appeared from the brand, such as binding of principal agreement that which does not fulfill the conditions of the validity of the agreement or the collateral agreement which is not perfect the binding, even on the brand certificates is possibly to be cancel. When those occur it will harm the bank as a creditor because the bank's position is not as a preferred creditor but only as a concurrent creditor.

\section{NOTES}

1. Berdasarkan Pasal 43 Peraturan otoritas Jasa Keuangan Nomor 40/POJK.03/2019 tentang Penilaian Kualitas Aset Bank Umum

2. Ratna Januarita, Risiko Hukum, https://crmsindonesia.org/publications/mengenai-risiko-hukum/

3. https://www.bi.go.id/id/Kamus.aspx access date: 30 January 2020

4. https://thelawdictionary.org/, diakses pada tanggal 30 Januari 2020

5. Menurut Penjelasan Pasal 76 ayat (2) UU Merek dan Indikasi Geografis yang dimaksud dengan pemilik merek yang tidak terdaftar antara lain pemilik merek yang beritikad baik tetapi tidak terdaftar atau pemilik merek terkenal tetapi mereknya tidak terdaftar

6. Novianti, Perlindungan Hukum Pemegang merek terkenal dalam Perspektif Paris Covention dan Undang-Undang Merek, https://berkas.dpr.go.id/puslit/files/buku_tim/buku-tim-public-80.pdf. Diakses pada tanggal 31 Januari 2020.

7. Novianti, Perlindungan Hukum Pemegang merek terkenal dalam Perspektif Paris Covention dan Undang-Undang Merek, https://berkas.dpr.go.id/puslit/files/buku_tim/buku-tim-public-80.pdf. diakses pada tanggal 31 Januari 2020.

8. Xuan-Thao Nguyen and Erisk D. Hile, The Puzzle in financing with trademark collateral, http://www.law.uh.edu/ipil/symposium/2018/6778-the-puzzle-in-financing-with-trademark-collateral.pdf. Diakses pada tanggal 31 Januari 2020 .

\section{REFERENCES}

1. Atikah, N. (2019) 'Pierre Cardin Trademark Dispute', Mulawarman Law Review. doi: 10.30872/mulrev.v4i1.51.

2. Bank Indonesia (1992) Undang-Undang Nomor 7 Tahun 1992 Tentang Perbankan, Bank Indonesia.

3. Cantika, D. P. (2018) 'Pembatalan Hak Merek Yang Telah Dijadikan Jaminan Fidusia', Jurnal Yuridis, 5(1), p. 7. doi: $10.35586 / . v 5 i 1.314$.

4. Djohanoputro, B. (2006) Manajemen Risiko Terintegrasi. Jakarta: PPM.

5. Djuwityastuti, dan Ahmad, F. (2019) 'Kajian Yuridis Sengketa Keabsahan Logo sebagai Sebuah Merek dan Hak Cipta', Jurnal Privat Law, VII(1), p. 90.

6. Januarita, R. (2020) Mengenai Risiko Hukum, CRMS Center for Risk Management \& Sustainability. Available at: https://crmsindonesia.org/publications/mengenai-risiko-hukum/ (Accessed: 30 January 2020).

7. Mulyani, S. (2012) 'PENGEMBANGAN HAK KEKAYAAN INTELEKTUAL SEBAGAI COLLATERAL (AGUNAN) UNTUK MENDAPATKAN KREDIT PERBANKAN DI INDONESIA', Jurnal Dinamika Hukum, 12(3), p. 571. doi: 10.20884/1.jdh.2012.12.3.128.

8. Nguyen, Xuan-Thao and Hile, E. D. (2018) 'The Puzzle in financing with trademark collateral', Houston law review / University of Houston.

9. Novianti (2017) Perlindungan Hukum Pemegang merek terkenal dalam Perspektif Paris Covention dan Undang-Undang Merek. Jakarta: Yayasan Pustaka Obor Indonesia. Available at: https://berkas.dpr.go.id/puslit/files/buku_tim/buku-tim-public-80.pdf. 
Вісник Харківського національного університету імені В. Н. Каразіна. Серія «ПРАВО». Випуск 29, 2020 The Journal of V.N. Karazin Kharkiv National University. Series: "Law". ISSUE 29, 2020

10. Presiden Republik Indonesia (1999) Undang-Undang Nomor 42 Tahun 1999 Tentang Jaminan Fidusia (Lembaran Negara Republik Indonesia Tahun 1999 Nomor 168, Tambahan Lembaran Negara Republik Indonesia Nomor 3889).

11. Presiden Republik Indonesia (2016) Undang-Undang Nomor 20 Tahun 2016 tentang Merek. (Lembaran Negara Republik Indonesia Tahun 2016 Nomor 252, Tambahan Lembaran Negara Republik Indonesia Nomor 5953).

12. Presiden Republik Indonesia (2019) Peraturan otoritas Jasa Keuangan Nomor 40/POJK.03/2019 tentang Penilaian Kualitas Aset Bank Umum

13. Sjadeini, S. R. (1994) Kebebasan Berkontrak dan Perlindungan Yang seimbang Bagi Para Pihak Dalam Perjanjian Kredit Bank Di Indonesia. Jakarta: Institut Bakir Indonesia.

14. The Law Dictionary (2020) The Law Dictionary. Available at: https://thelawdictionary.org/

15. Usanti, Trisadini Prasastinah, dkk (2017) Analisis Risiko Hukum Atas Jaminan Sertifikat Hak Atas Merek dalam Transaksi Perbankan, PTUPT, DRPM Kemenristek.

16. Usanti, Trisadini Prasastinah dan Silvia, F. (2018) 'The Prudential Principle of Trademark as The Object of Secured Transacti on in Financing', in 3rd Internasional Conference Islamic Law in Indonesia. Samarinda.

17. Usanti, T. P. (2017) 'Analisis Pembebanan Gadai Atas Sertifikat Hak Merek di Bank Syariah', Jurnal Mimbar Hukum, 29(3).

18. Widodo, I. G. et al. (2019) 'Constraints on Enforcement of Environmental Law Against Corporate Defendants', Environmental Policy and Law. doi: 10.3233/EPL-190129. 